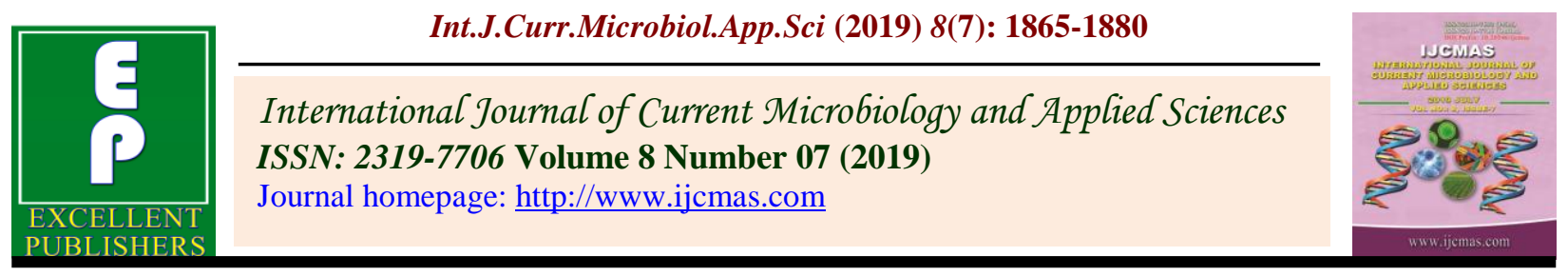

Original Research Article

https://doi.org/10.20546/ijcmas.2019.807.222

\title{
Isolation and Characterization of Potential Zn Solubilizing Rhizobacteria from Cumin (Cuminum cyminum)
}

\author{
Dhanni Devi ${ }^{*}$, S.B. Gupta ${ }^{1}$ and B.K. Mishra ${ }^{2}$ \\ ${ }^{1}$ Department of Agricultural Microbiology, CoA, IGKV, Raipur (C.G.)-492012, India \\ ${ }^{2}$ National Research Centre on Seed Spices, Tabiji, Ajmer (Raj.)-305206, India \\ *Corresponding author
}

\section{A B S T R A C T}

The present investigation was carried out during the year 2017-18 in Laboratory of Microbiology, Division of Crop Production, ICAR-National Research Centre for Seed spices Ajmer, Rajasthan. The aim of study was to isolate potential Zn solubilizing plant growth promoting rhizobacteria from rhizosphere soil and plants of cumin. For this investigation 155 soil and plant samples were collected from Ajmer, Nagaur Jodhpur,

\begin{tabular}{|l|}
\hline Keyw or d s \\
Cumin, Zn \\
solubilizing \\
bacteria, Plant \\
growth promoting \\
rhizobacteria
\end{tabular}
Jaisalmer, Barmer, Jalore districts of Rajasthan. From 155 samples, 153 isolates were collected and out of 153, 23 isolates were $\mathrm{Zn}$ solubilizers. However $23 \mathrm{Zn}$ solubilizing rhizobacteria were selected for further studies viz., Qualitative and quantitative estimation of $\mathrm{Zn}$ in vitro and characterized them against biochemical identification and evaluate for plant growth promoting traits. In qualitative study of $\mathrm{Zn}$ estimation, highest solubilization zone was $26 \mathrm{~mm}$ due to isolate DCU-451 followed by 21, 20 and $19 \mathrm{~mm}$ associated with DCU-453, DCU-188 and DCU-184, respectively, and least solubilization zone was $12 \mathrm{~mm}$ due to isolate DCU-460. Similarly highest solubilization index was found 3.7 due to isolate 451 followed by $3.4,3.3$ and 3.2 were associated with rhizobacterial isolates DCU-453, 184 and 188 respectively, and lowest SI was 2.2 due to isolate DCU-169. In quantitative assay at 5 days highest amount of released Zn was found $152 \mu \mathrm{g}$ followed by $144,141 \mu \mathrm{g}$ $/ \mathrm{ml}$ due to isolate DCU-453, DCU-451 and DCU-188, respectively, and least was $81 \mu \mathrm{g} / \mathrm{ml}$ in DCU-176. At 10 days highest amount of released $\mathrm{Zn}$ was found $268 \mu \mathrm{g}$ followed by $253,238 \mu \mathrm{g} / \mathrm{ml}$ due to isolate DCU-451, DCU-453 and DCU-172, respectively, and least was $117 \mu \mathrm{g} / \mathrm{ml}$ in DCU-165. Similar results were found at 15 days also, that were highest amount of released $\mathrm{Zn}$ was found $419 \mu \mathrm{g}$ followed by $391,389 \mu \mathrm{g} / \mathrm{ml}$ associated with DCU-451, DCU-188 and DCU-453, respectively, and least was $184 \mu \mathrm{g} / \mathrm{ml}$ in DCU-198. However rhizobacterial isolate DCU-451 was found superior in both qualitatively and quantitatively.

\section{Introduction}

Cumin (Cuminum cyminum) is a member of Umbelliferae (Apiaceae) family and an annual plant, which is widely cultivated in arid and semi-arid regions. Cumin has along history of use as food flavours, perfumes and medicine. In addition to its common use as spice in our daily life, recent studies have indicated its pharmaceutical and medicinal importance. Total area, total production and yield of cumin in India is 966170 hectare, 688660 tonnes and 
$713 \mathrm{~kg}$ per hectare, respectively, (Directorate of arecanut and spices development, Calicut, 2017-18). Among seed spices, cumin is an important crop of western Rajasthan and is mainly grown in the districts of Jaisalmer, Jalore, Pali, Barmer, Ajmer, Nagaur, Tonk and Jodhpur. In fact, the extreme susceptibility to disease like wilt, powdery mildew and blight and also to aphids and lack of knowledge of suitable agricultural practices are the reasons of poor productivity in this crop. There is no doubt that this crop has tremendous scope and the availability of suitable improved practices will result in increase in area as well as production by solving the above constraints.

Cumin (Cuminum cyminum L.) is an aromatic plant from the Apicaceae family and its seeds has been used as a spice from ancient times, being mentioned also in the Bible (Sahana et al., 2011). The seeds are used in cooking, while volatile oil it is useful in flavouring foods but also in cosmetics and perfume industries (Dubey et al., 2017). Cumin is the second most important spice in the world, after black pepper (Pepper nigrum), according to (Sowbhagya, 2013; Mnif et al., 2015).

Cumin known as zeera, could be cultivated in the plains areas, semi-arid regions, but also in the hills, being resistant to water deficit and having a seeds production of about 12000 tons per year (RezaeiChiyaneh et al., 2018). Apicaceae family is one of the biggest plant families, including 455 genera and over 3500 species (Bhmankar et al., 2018). As reported by the literature, Cuminum cyminum may have positive effects on metabolic disorders like hyperglycemia, dyslipidemia, on weight reduction and could ameliorate insulin function, preventing the progression of diabetes (Jafari et al., 2018 and Rostami et al., 2018) described that cumin could have beneficial effect on digestion, flatulence, diarrhea and possess antioxidant and antispasmodic properties.
Bacteria are known to immobilize metal by precipitation and adsorption. The ability to dissolve immobilized zinc viz. zinc phosphate, zinc oxide and zinc carbonate in appreciable quantity is not common feature amongst the cultivable bacteria. Few $\mathrm{Zn}$ solubilizing bacterial genera viz., Thiobacillus thioxidans, Thiobacillus ferroxidans, Acinetobacter, Bacillus, Gluconacetobacter, Pseudomonas and facultative thermophilic iron oxidizers have been reported as zinc solubilizers (Saravanan et al., 2007). Zinc-solubilizing microorganisms can solubilize zinc from inorganic and organic pools of total soil zinc and can be utilized to increase zinc availability to plants. Fungi have been extensively studied for solubilization of insoluble zinc compounds both in vitro and in vivo. However, only some bacterial species of the genera Acinetobacter, Bacillus, Gluconacetobacter, and Pseudomonas have been reported (Gadd, 2007).

\section{Materials and Methods}

The present investigation was carried out in Microbiology laboratory Division of Crop production, ICAR-NRCSS, Tabiji, Ajmer for isolation and characterization of zinc solubilizing bacteria from cumin rhizosphere and plant itself.

\section{Collection of samples}

A total of 155 soil and plant samples were collected from cumin grown agricultural fields of Ajmer, Barmer, Jalore, Nagaur, Jaisalmer and Jodhpur Districts of Rajasthan (India). All rhizospheric soil samples were collected from $0-15 \mathrm{~cm}$ depth by carefully uprooting the plants and for endophytes healthy cumin roots were collected. The samples were properly tagged, sealed and stored. Collected soil samples were preserved in a polythene bag for physico-chemical properties and microbial analysis. 


\section{Isolation of rhizobacteria}

The isolation of rhizobacteria from cumin roots as well as rhizosphere soil of cumin was done using six different media viz. Nutrient agar (NA) and Zinc solubilizing agar medium for $\mathrm{Zn}$ solubilizing microbes. All the media were prepared and autoclaved at 15 psi and $121^{\circ} \mathrm{C}$ for 20 minutes.

\section{Isolation of rhizobacteria from rhizospheric soil}

Ten grams of the fresh soil was transferred to Erlenmeyer flask $(150 \mathrm{ml})$ containing $90 \mathrm{ml}$ sterile distilled water $\left(10^{-1}\right)$ and was shaken at $120 \mathrm{rpm}$ for $15 \mathrm{~min}$. Then, $1.0 \mathrm{~mL}$ of this suspension was transferred into a $9 \mathrm{~mL}$ blank $\left(10^{-2}\right)$. This serial dilution was continued up to $10^{-10}$, followed by pour plating on Nutrient agar (NA) and Zinc solubilizing agar medium. The petri plates were inoculated and incubated for $24-48 \mathrm{hrs}$ at $28^{\circ} \mathrm{C}$. Colonies which appeared to be morphologically different were isolated and subcultured.

\section{Isolation of rhizobacteria from cumin roots}

The collected plant material used for the isolation was first surface sterilized following the method of Santos et al., (2003) with few modifications. Plant material was first cleaned by washing several times under running tap water then Surface sterilization was performed by sequentially rinsing the plant material with $70 \%$ ethanol $\left(\mathrm{C}_{2} \mathrm{H}_{5} \mathrm{OH}\right)$ for 30 seconds, then with $0.01 \%$ mercuric chloride $\left(\mathrm{HgCl}_{2}\right)$ for 5 minutes followed by $0.5 \%$ sodium hypochlorite $(\mathrm{NaOCl})$ for 2-3 minutes and finally with sterile distilled water for 2-3 times. Plant roots were then dried in between the folds of sterile filter papers. After proper drying, the surface sterilized roots were cut vertically into small segments each segment was placed on different types of medium. All the plates were incubated at $28^{\circ} \mathrm{C}$ to promote the growth of endophytes and were regularly monitored for any microbial growth. On observing the microbial growth, sub culturing was done. Each endophytic culture was checked for purity and transferred to freshly prepared medium plate. Appropriate controls were also set up in which no plant tissues were inoculated.

\section{Screening for solubilizing rhizobacteria}

All the bacterial isolates were tested for their ability to solubilize the insoluble form Zinc oxide, on Zinc solubilizing agar for isolate Zinc solubilizing bacteria, respectively. 23 rhizobacteria were obtained those had capacity to solubilizing $\mathrm{Zn}$ in vitro . Out of these 23, some isolates also had able to solubilize another mineral like $\mathrm{P}$ and $\mathrm{K}$ depicted in Table 1 .

\section{Biochemical characterization of rhizobacteria}

Biochemical characterization of bacterial isolates was done on the basis of catalase production, nitrate reduction, starch hydrolysis and methyl red test. These were conducted as per the standard methods (Cappuccino and Sherman 1992).

\section{Catalase production}

A drop of $3 \% \mathrm{H}_{2} \mathrm{O}_{2}$ was taken on a glass slide and small amount of bacterial culture was mixed with platinum inoculation loop. Rapid and sustained production of gas bubbles or effervescence constituted positive test.

\section{Nitrate reduction tes}

$5 \mathrm{ml}$ nitrate broth was inoculated with pure culture of the test organism. It was incubated at $28^{\circ} \mathrm{C}$ for 48 hours. Equal volume $(0.5 \mathrm{ml})$ of both the reagents A (Sulfanilicacid $8 \mathrm{~g}+$ Acetic acid $1000 \mathrm{ml})$ and B (5 g 
Alphanaphthylamine $+5 \mathrm{~N}$ Acetic acid 1000 $\mathrm{ml}$ ) were added. The development of red color within 30 seconds indicated the positive test.

\section{Hydrolysis ofstarch}

Sterilized starch agar medium was poured onto petriplates. The log phase cultures were spotted on the plates and incubated at $28^{\circ} \mathrm{C}$ for $48 \mathrm{hrs}$.

After full growth of cultures, the petriplates were flooded with Gram's iodine. The hydrolysis of starch was observed as a colorless zone surrounding the colonies against purple background. A blue or purple zone indicated that starch was nothydrolyzed.

\section{Methyl red (MR) test}

Dye was dissolved in alcohol followed by addition of water to make $100 \mathrm{ml}$ volume. It was stored at room temperature.

A tube of GPPW $(5 \mathrm{ml})$ was inoculated with pure culture of the test organism. It was incubated at $28^{\circ} \mathrm{C}$ for 48 hours.

At the end of this, 5 drops of the MR reagent was added directly to the broth. The development of a stable red color indicated positive test.

\section{HiAssorted biochemical test}

Each HiAssorted ${ }^{\mathrm{TM}}$ Biochemical Test kit is a standardized colorimetric identification system utilizing seven conventional biochemical tests and five carbohydrate utilization tests. The tests are based on the principle of $\mathrm{pH}$ change and substrate utilization. On incubation organisms undergo metabolic changes which are indicated by a colour change in the media that can be either interpreted visually or after addition of the reagent.

\section{Qualitative assay for $\mathrm{Zn}$ solubilization}

One loop full of overnight matured cultures of $\mathrm{Zn}$ solubilising bacterial isolates were spotted on zinc solubilizing agar medium to observe the zone of solubilisation/clearance by the isolates.

The plates were incubated at $28 \stackrel{\circ}{\mathrm{C}}$ for $48 \mathrm{~h}$ and the zone of solubilisation/clearance was observed and expressed in $\mathrm{mm}$. SI was measured using the following formula (Premono et al., 1996).

SI $=($ Colony diameter + Halo zone formation $)$ / (Colony diameter)

\section{Quantitative assay for Zn solubilization}

The ZSB isolates that showed halo zone formation were further tested for their ability to release inorganic $\mathrm{Zn}$ from insoluble $\mathrm{ZnO}$ using Atomic Absorption Spectrometer (Varian AAS 240 FS).

The ZSB were grown in $50.0 \mathrm{~mL} \mathrm{Zn}$ solubilising broth at $28^{\circ} \mathrm{C}$ for different interval of days $\left(5^{\text {th }}\right.$ day, $10^{\text {nd }}$ day and 10 th day) with three replicates in incubator cum shaker at 120 rpm along with their controls.

After $24 \mathrm{~h}$ of incubation, cultures and control were withdrawn and transferred aseptically to centrifuge tubes. They were centrifuged at $8,000 \mathrm{rpm}$ for $15 \mathrm{~min}$ at $4^{\circ} \mathrm{C}$. The supernatant was collected in test tubes. Then $1.0 \mathrm{~mL}$ aliquot from the supernatant was transferred to $50.0 \mathrm{~mL}$ standard flask and the volume was made up to $50.0 \mathrm{~mL}$ using distilled water.

The soluble $\mathrm{Zn}$ was estimated from standard curve by plotting readings drawn from standard solution against $\mathrm{mg}$ of $\mathrm{Zn}$ taken. The same procedure was followed for the remaining sampling days along with their respective controls. 


\section{Determination of $\mathbf{p H}$}

The $\mathrm{pH}$ of the ZSB culture filtrates and the uninoculated samples was determined at 5, 10 and 15 days after inoculation. The culture was filtered using Whatman No.1 filter paper. The $\mathrm{pH}$ was estimated using Elico $\mathrm{pH}$ meter.

\section{Statistical analysis}

Statistical analysis of data was carried out using online statistical analysis pack- age (OPSTAT, Computer section, CCS HAU Hisar, Haryana) for calculation of ANOVA.

\section{Results and Discussion}

Results of biochemical tests were depicted in Table 4.

\section{Qualitatively assay of $\mathrm{Zn}$ solubilization in vitro}

Bacterial isolates were tested for halo zone formation by plate assay using zinc soulubilizing agar medium containing $0.1 \%$ zinc oxide. The halo zone and colony diameters were measured after the incubation of plates at $28^{\circ} \mathrm{C}$. Table 2 shows data on zinc solubilization by bacterial isolates on qualitative basis. The efficacy of $\mathrm{P}$ solubilization by individual isolate on agar medium was shown in Plate 4.1. Based on halo zone formed by an isolates, solubilization index (SI) was calculated. SI ranged from 2.23.7. Highest solubilization zone was $26 \mathrm{~mm}$ due to isolate DCU-451 followed by 21,20 and $19 \mathrm{~mm}$ associated with DCU-453, DCU188 and DCU-184, respectively, and least solubilization zone was $12 \mathrm{~mm}$ due to isolate DCU-460. Similarly highest solubilization index was found 3.7 due to isolate 451 followed by $3.4,3.3$ and 3.2 were associated with rhizobacterial isolates DCU-453, 184 and 188 respectively, and lowest SI was 2.2 due to isolate DCU-169. Variation in solubilization index by 23 isolates depicted in Table 2 and Figure 1. Solubilization zone of potential isolates DCU-451, DCU-188 and DCU-451 were showing in Plate-1.similarly, Gandhi et al., (2014) isolated 240 zinc solubilizing bacterial strains from rhizosphere of rice. Similar observations noticed by Bhagwan Singh et al., (2017). They reported that $\mathrm{Zn}$ solubilizing isolate $\mathrm{ZnSF}-1$ showed maximum solubilization zone of $85 \mathrm{~mm}$ followed by ZnSF-2 with $34 \mathrm{~mm}$ for $\mathrm{ZnO}$. The solubilization zone is ranged from $6 \mathrm{~mm}$ to 25 $\mathrm{mm}$ for $\mathrm{ZnP}$. The isolate $\mathrm{ZnSB}-8$ showed maximum solubilization zone of $25 \mathrm{~mm}$ for zinc phosphate. The solubilization efficiency (\%) ranges from 157.14 to $500 \%$ which was maximum for ZnSB-8 (500.0 \%) and least for ZnSB- 6 (157.14 \%).

\section{Qualitatively assay of $\mathrm{Zn}$ solubilization in vitro}

Zinc solubilisation by rhizobacterial isolates were studied using zinc solubilizing medium broth inoculated with respective isolates and incubated for 15 days. To study the efficiency of zinc solubilisation by the isolates, zinc solubilisation was calculated at different time interval. At 5 days highest amount of released $\mathrm{Zn}$ was found $152 \mu \mathrm{g}$ followed by $144,141 \mu \mathrm{g}$ $/ \mathrm{ml}$ due to isolate DCU-453, DCU-451 and DCU-188, respectively, and least was $81 \mu \mathrm{g}$ $/ \mathrm{ml}$ in DCU-176. At 10 days highest amount of released $\mathrm{Zn}$ was found $268 \mu \mathrm{g}$ followed by 253, $238 \mu \mathrm{g} / \mathrm{ml}$ due to isolate DCU-451, DCU-453 and DCU-172, respectively, and least was $117 \mu \mathrm{g} / \mathrm{ml}$ in DCU-165. Similar results were found at 15 days also, that were highest amount of released $\mathrm{Zn}$ was found 419 $\mu \mathrm{g}$ followed by $391,389 \mu \mathrm{g} / \mathrm{ml}$ associated with DCU-451, DCU-188 and DCU-453, respectively, and least was $184 \mu \mathrm{g} / \mathrm{ml}$ in DCU-198.Variation of isolate for released $\mathrm{Zn}$ and reduction in $\mathrm{pH}$ was observed in all cultures over incubation time shown in Table 3 , Figure 2 and 3. 
Plate-1 Solubilization of $\mathrm{Zn}$ on zinc solubilizing agar media by potential rhizobacteria from cumin

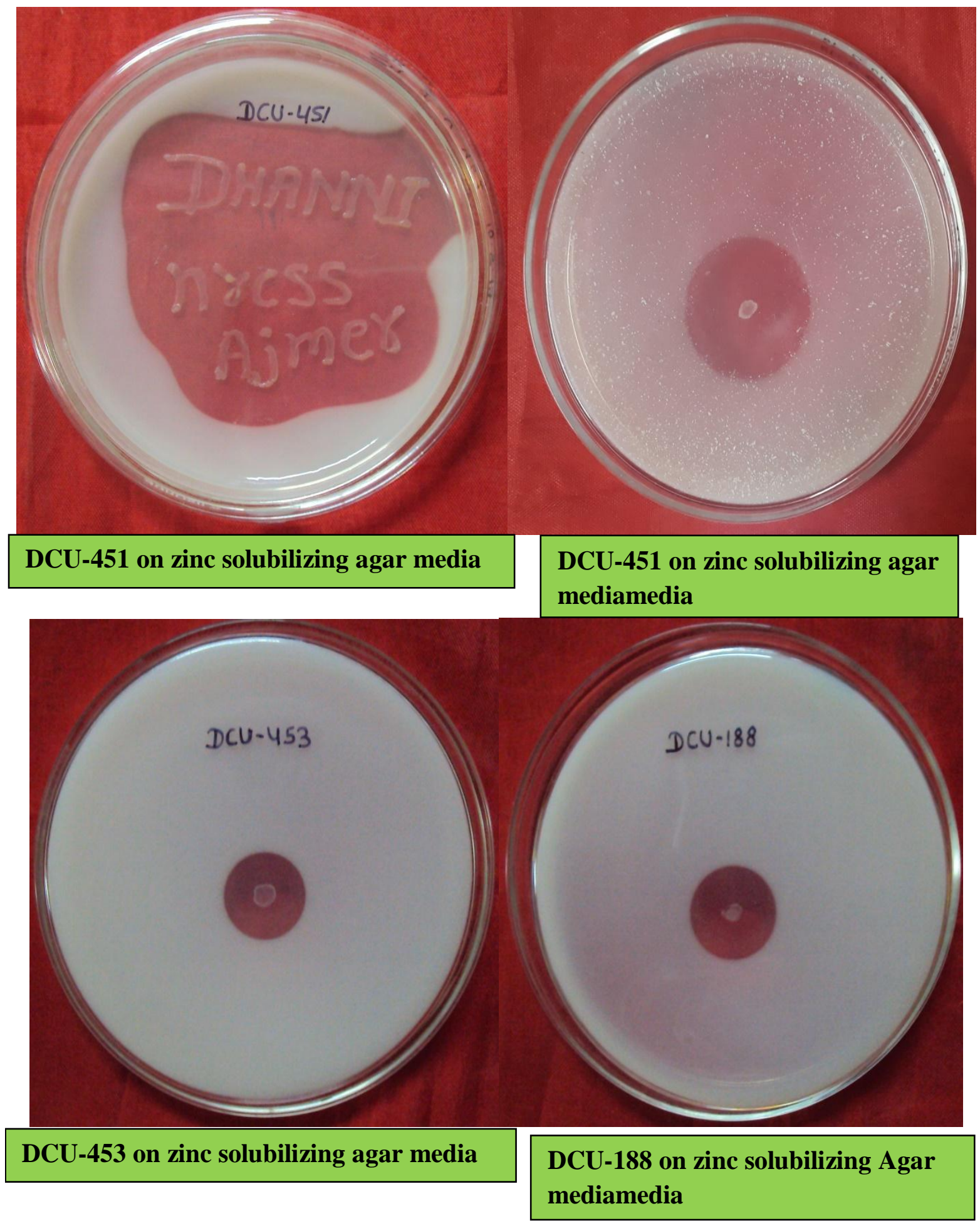


Plate-2 Biochemical test and quantitatively zinc estimation

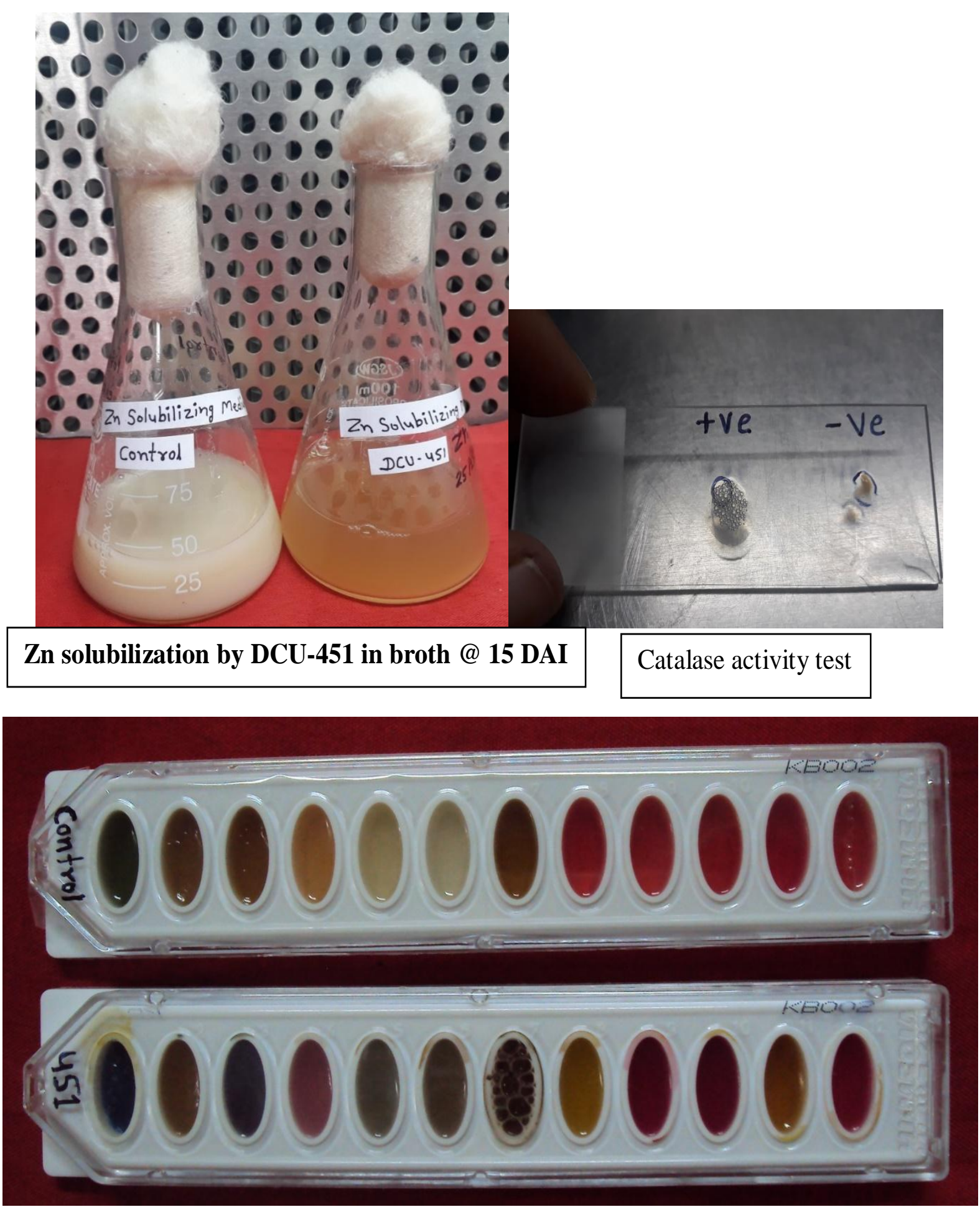

Biochemical tests of DCU-451 usingHiAssorted Biochemical test kit 


\begin{tabular}{|c|c|c|c|c|}
\hline S.N. & Isolates & PSolubilizers & K Solubilizers & Zn Solubilizers \\
\hline 1 & DCU-112 & + & - & + \\
\hline 2 & DCU-121 & + & + & + \\
\hline 3 & DCU-154 & - & - & + \\
\hline 4 & DCU-157 & - & - & + \\
\hline 5 & DCU-159 & - & - & + \\
\hline 6 & DCU-162 & - & - & + \\
\hline 7 & DCU-165 & - & - & + \\
\hline 8 & DCU-169 & - & - & + \\
\hline 9 & DCU-172 & - & - & + \\
\hline 10 & DCU-176 & - & - & + \\
\hline 11 & DCU-181 & - & - & +++ \\
\hline 12 & DCU-183 & - & - & + \\
\hline 13 & DCU-184 & + & - & +++ \\
\hline 14 & DCU-187 & - & - & + \\
\hline 15 & DCU-188 & + & - & ++ \\
\hline 16 & DCU-195 & - & - & + \\
\hline 17 & DCU-197 & - & - & + \\
\hline 18 & DCU-198 & - & - & + \\
\hline 19 & DCU-251 & + & + & + \\
\hline 20 & DCU-451 & + & + & +++ \\
\hline 21 & DCU-453 & + & + & +++ \\
\hline 22 & DCU-460 & - & - & + \\
\hline 23 & DCU-651 & + & + & + \\
\hline
\end{tabular}




\begin{tabular}{|c|c|c|c|}
\hline \multicolumn{4}{|c|}{ Table.2 Qualitatively estimation of soluble $\mathrm{Zn}$ by potential PGPR isolates } \\
\hline S.N. & Isolates & Solubilization zone $(\mathrm{mm})$ & Solubilization Index \\
\hline 1. & DCU-460 & 12 & 2.6 \\
\hline 2. & DCU-181 & 17 & 3 \\
\hline 3. & DCU-184 & 19 & 3.3 \\
\hline 4. & DCU-188 & 20 & 3.2 \\
\hline 5. & DCU-251 & 18 & 3.0 \\
\hline 6. & DCU-112 & 15 & 2.7 \\
\hline 7. & DCU-121 & 18 & 2.5 \\
\hline 8. & DCU-154 & 14 & 2.8 \\
\hline 9. & DCU-157 & 15 & 2.9 \\
\hline 10. & DCU-159 & 16 & 2.8 \\
\hline 11. & DCU-162 & 15 & 2.6 \\
\hline 12. & DCU-165 & 14 & 2.5 \\
\hline 13. & DCU-169 & 17 & 2.2 \\
\hline 14. & DCU-172 & 16 & 2.4 \\
\hline 15. & DCU-176 & 15 & 2.8 \\
\hline 16. & DCU-183 & 16 & 2.6 \\
\hline 17. & DCU-187 & 18 & 2.7 \\
\hline 18. & DCU-195 & 15 & 3.2 \\
\hline 19. & DCU-197 & 17 & 2.5 \\
\hline 20. & DCU-198 & 16 & 2.4 \\
\hline 21. & DCU-451 & 26 & 3.7 \\
\hline 22. & DCU-453 & 21 & 3.4 \\
\hline \multirow[t]{4}{*}{23.} & DCU-651 & 13 & 2.6 \\
\hline & SEm & 0.983 & 0.112 \\
\hline & $\mathrm{CD}$ & 2.106 & 0.223 \\
\hline & $\mathrm{CV}$ & 4.212 & 3.734 \\
\hline
\end{tabular}


Table.3 Quantitatively estimation of $\mathrm{Zn}$ released by rhizobacterial isolates in zinc solubilizing medium broth

\begin{tabular}{|c|c|c|c|c|c|c|c|}
\hline \multirow[t]{2}{*}{ S.N. } & \multirow[t]{2}{*}{ Isolates } & \multicolumn{2}{|l|}{5 Days } & \multicolumn{2}{|l|}{10 Days } & \multicolumn{2}{|l|}{15 Days } \\
\hline & & Soluble $\mathrm{Zn}(\mu \mathrm{g} / \mathrm{ml})$ & pH & Soluble $\mathrm{Zn}(\mu \mathrm{g} / \mathrm{ml})$ & pH & Soluble Zn ( $\mu \mathrm{g} / \mathrm{ml})$ & pH \\
\hline 1. & DCU-460 & 118 & 6.45 & 198 & 6.12 & 362 & 6.0 \\
\hline 2. & DCU-181 & 121 & 6.78 & 219 & 5.65 & 363 & 5.54 \\
\hline 3. & DCU-184 & 138 & 6.35 & 223 & 5.41 & 384 & 5.30 \\
\hline 4. & DCU-188 & 141 & 6.67 & 253 & 5.82 & 391 & 5.53 \\
\hline 5. & DCU-251 & 130 & 6.45 & 226 & 6.36 & 358 & 6.34 \\
\hline 6. & DCU-112 & 96 & 6.84 & 187 & 6.31 & 259 & 5.98 \\
\hline 7. & DCU-121 & 82 & 6.65 & 145 & 6.42 & 257 & 5.81 \\
\hline 8. & DCU-154 & 126 & 6.29 & 211 & 6.12 & 269 & 5.82 \\
\hline 9. & DCU-157 & 94 & 6.94 & 168 & 6.40 & 297 & 6.14 \\
\hline 10. & DCU-159 & 116 & 6.47 & 215 & 6.15 & 275 & 5.86 \\
\hline 11. & DCU-162 & 88 & 6.36 & 184 & 5.84 & 212 & 5.51 \\
\hline 12. & DCU-165 & 95 & 6.72 & 117 & 6.46 & 187 & 6.22 \\
\hline 13. & DCU-169 & 133 & 6.81 & 241 & 6.28 & 352 & 6.12 \\
\hline 14. & DCU-172 & 133 & 6.96 & 238 & 5.86 & 373 & 5.47 \\
\hline 15. & DCU-176 & 81 & 6.62 & 126 & 6.11 & 195 & 5.76 \\
\hline 16. & DCU-183 & 92 & 6.69 & 158 & 6.47 & 198 & 5.92 \\
\hline 17. & DCU-187 & 125 & 6.46 & 226 & 6.32 & 258 & 6.11 \\
\hline 18. & DCU-195 & 128 & 6.47 & 216 & 6.23 & 299 & 6.37 \\
\hline 19. & DCU-197 & 83 & 6.37 & 183 & 5.98 & 191 & 5.30 \\
\hline 20. & DCU-198 & 94 & 5.96 & 194 & 5.14 & 184 & 5.71 \\
\hline 21. & DCU-451 & 144 & 6.10 & 268 & 5.16 & 419 & 4.81 \\
\hline 22. & DCU-453 & 152 & 6.26 & 236 & 5.84 & 389 & 5.63 \\
\hline 23. & DCU-651 & 125 & 6.94 & 223 & 6.72 & 287 & 6.42 \\
\hline & SEm & 7.362 & & 10.384 & & 14.469 & \\
\hline & $\mathrm{CD}$ & 13.422 & & 21.351 & & 31.685 & \\
\hline & $\mathrm{CV}$ & 16.366 & & 11.713 & & 13.478 & \\
\hline
\end{tabular}


Table.4 Biochemical tests of Potential $\mathrm{Zn}$ solubilizing bacterial isolates

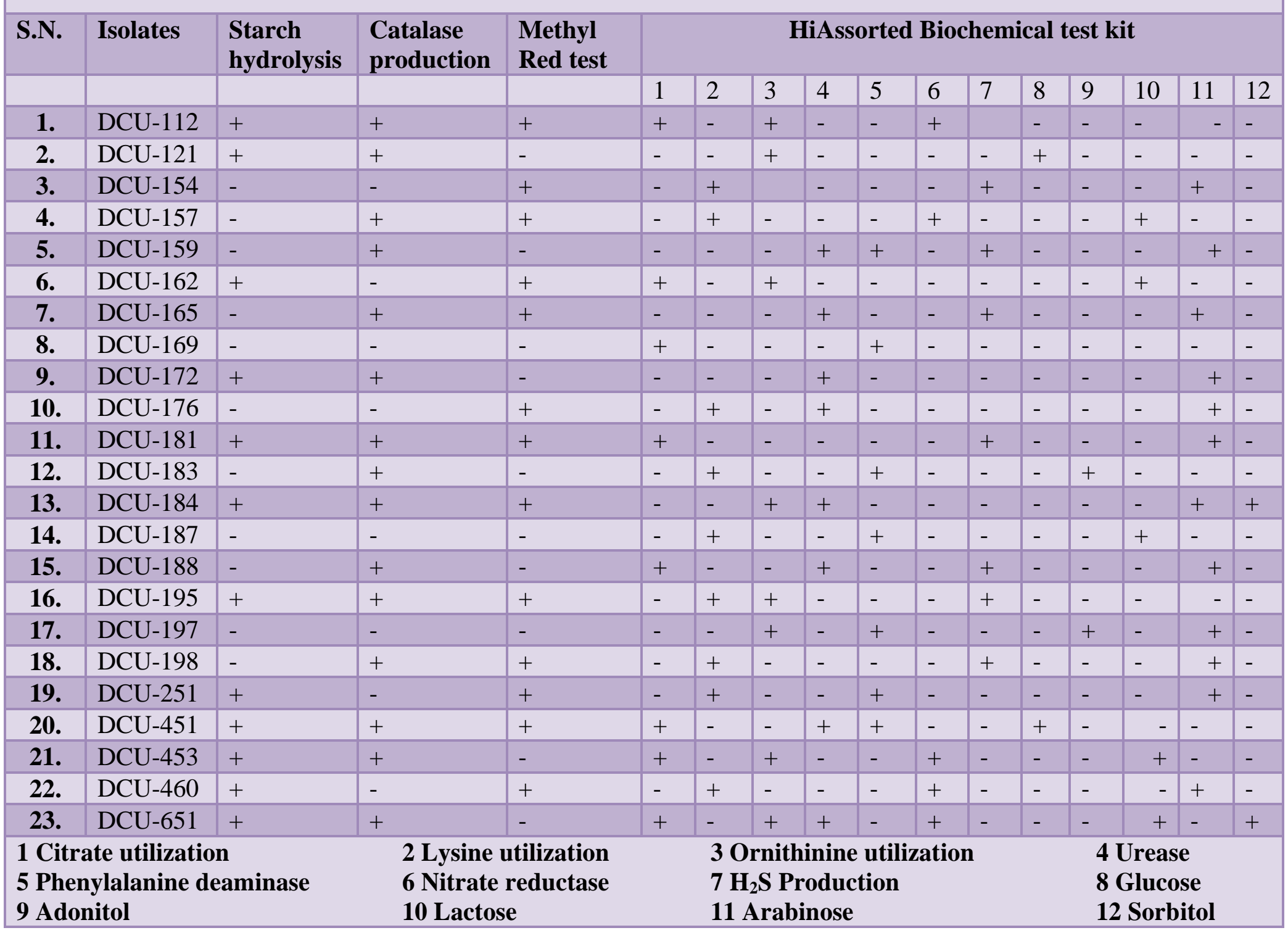




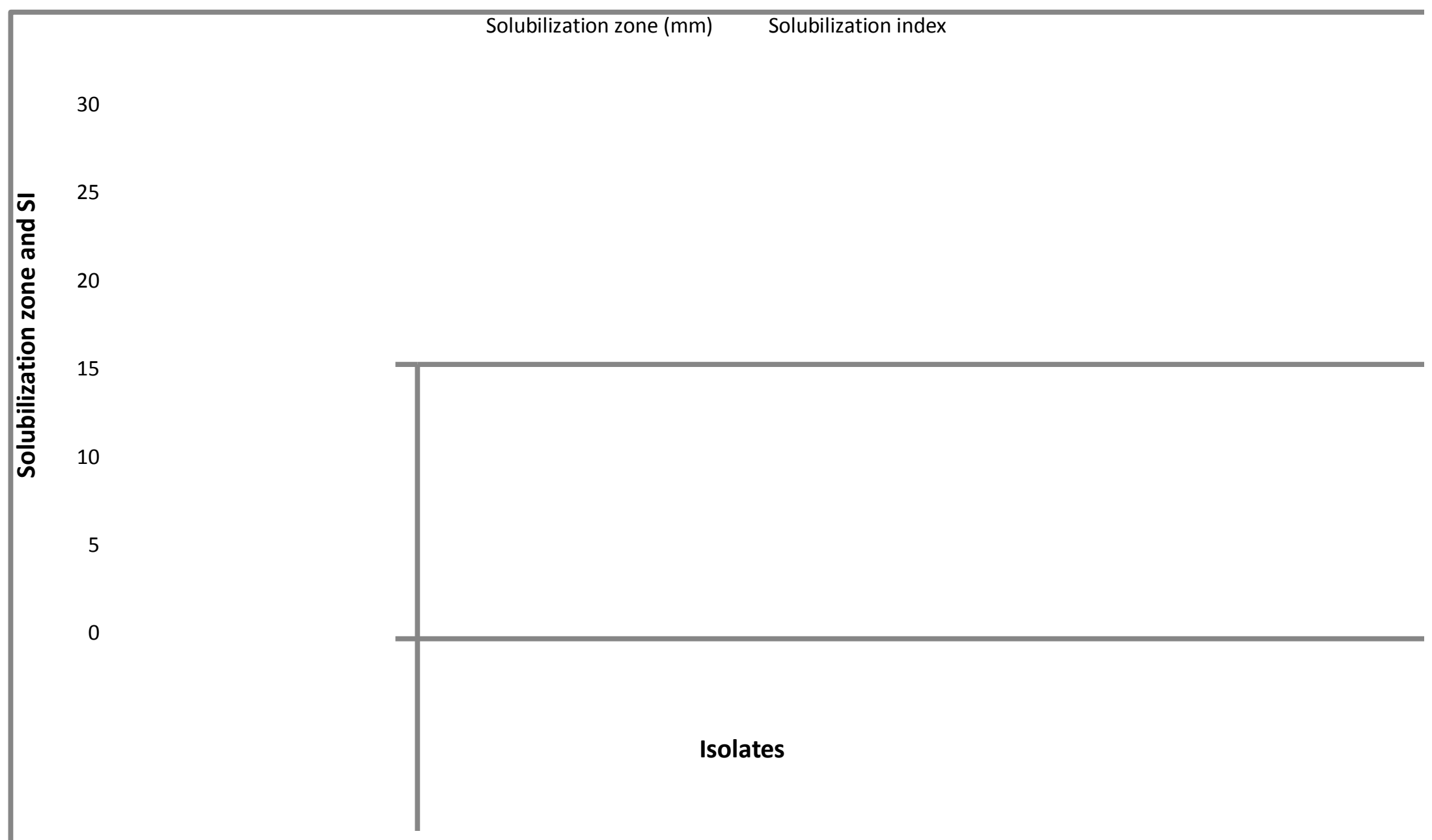

Fig.1 Showing Solubilization zone and solubilization index by zn solubilizing isolates on Zinc solubilizing Agar media 


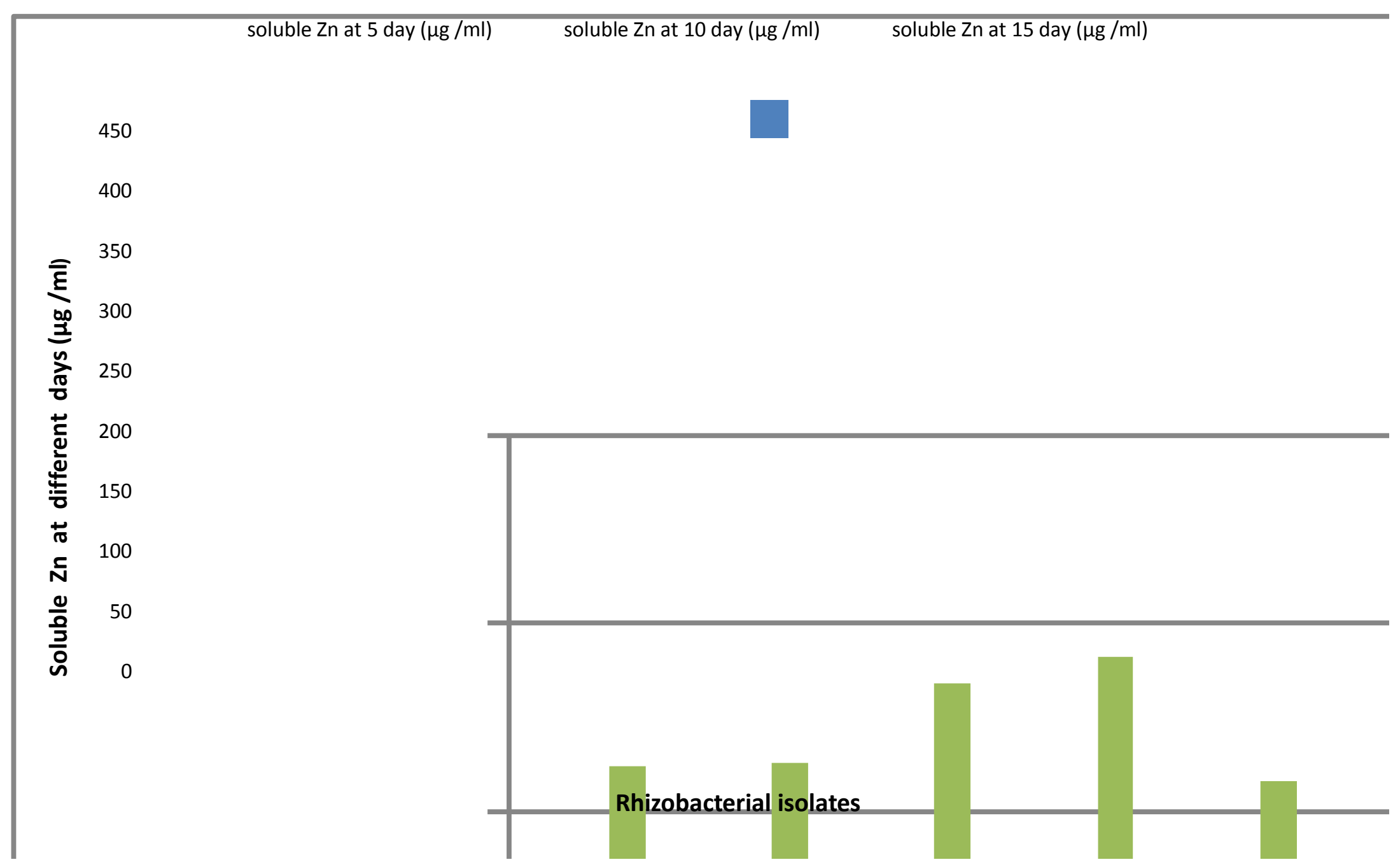

Fig.2 Showing amount of solubilized $\mathrm{Zn}$ by rhizobacterial isolates in $\mathrm{Zn}$ solubilizing medium broth containing Zinc oxide 


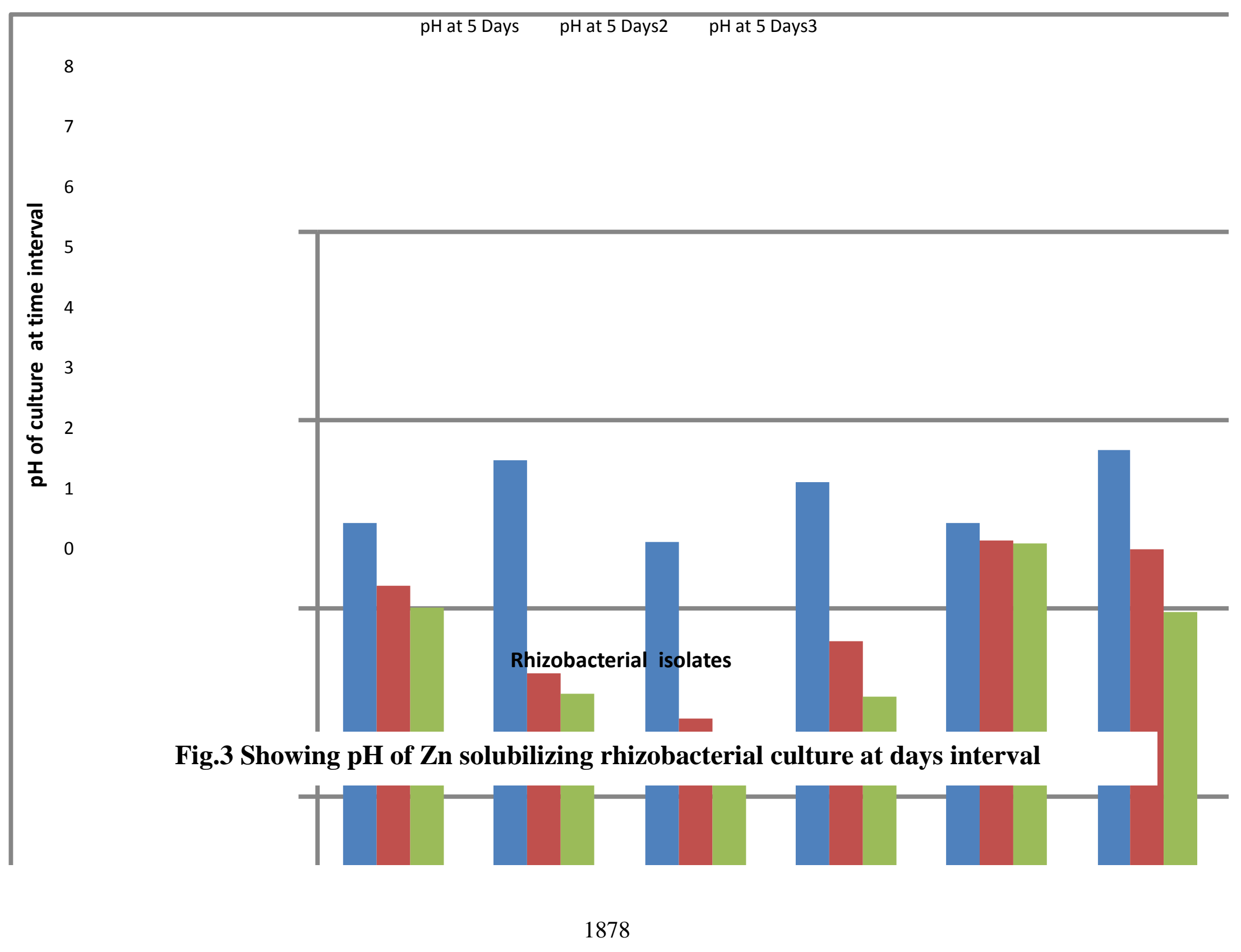


However the superior $\mathrm{Zn}$ solubilizing isolate was DCU-451, showing the strong ability to solubilize $\mathrm{Zn}$ in vitro (Plate-2). Isolates gives a clue that the solubilization could be due to production of organic acids. The more production of organic acid improves the available zinc in the culture broth. Similar observations noticed by Desai et al., (2012) reported that higher availability of $\mathrm{Zn}$ is directly proportional to acidic $\mathrm{pH}$ of the culture broth.

\section{Acknowledgement}

I am grateful to the Division of Crop Production, ICAR-NRCSS, Ajmer for providing facilities for this research.

\section{References}

Bahmankar, M., Mortazavian, S. M. M., Tohidfar, M., Sadat Noori, S. A., IzadiDarbandi, A. and Al-fekaiki, D. F. 2019. Chemotypes and morphophysiological characters affecting essential oil yield in Iranian cumin landraces. Industrial Crops and Products, 128: 256-269.

Bhagwan Singh Dhaked, S. Triveni, R. Subhash Reddy and Padmaja G. 2017.Isolation and Screening of Potassium and Zinc Solubilizing Bacteria from Different Rhizosphere Soil. Int.J.Curr.Microbiol.App.Sci. 6(8): 1271-1281.

Cappuccino, J. G. and Sherman, N. 1992. Biochemical activities of microorganisms. In: Microbiology, a laboratory manual. $1^{\text {st }}$ ed. California: The Benjamin/Cummings Publishing Co.; 105-300.

Desai, S., Kumar, P.G., Sultana, U., Pinisetty, S., Ahmed, M. H. S. K., Amalraj, L. D. E. and Reddy, G. 2012. Potential microbial candidate strains for management of nutrient requirements of crops. African Journal of Microbiology

Research. 6: 3924-3931.

Dubey, P. N., Saxena, S. N., Mishra, B. K., Solanki, R. K., Vishal, M. K., Singh, B. and Yogi, A. 2017. Preponderance of cumin (Cuminum cyminum) essential oil constituents across cumin growing Agro-Ecological Sub Regions, India. Industrial Crops and Products. 95: 5059.

Gandhi, A., Muralidharan, G., Sudhakar, E and Murugan, A. 2014. International Journal of Recent Scientific Research. 5: 2201-2204.

Jafari, T., Mahmoodnia, L., Tahmasebi, P., Memarzadeh, M. R., Sedehi, M., Beigi, M., and Fallah, A. A. 2018. Effect of cumin (Cuminum cyminum) essential oil supplementation on metabolic profile and serum leptin in pre-diabetic subjects: A randomized double-blind placebo-controlled clinical trial. Journal of Functional Foods. 47: 416-422.

Mnif, S., and Aifa, S. (2015). Cumin (Cuminum cyminum) from traditional uses to Potential Biomedical Applications. Chemistry and Biodiversity. 12(5): 733-742.

Rezaei-Chiyaneh, E., Seyyedi, S. M., Ebrahimian, E., Moghaddam, S. S. and Damalas, C. A. 2018. Exogenous application of gamma-aminobutyric acid (GABA) alleviates the effect of water deficit stress in black cumin (Nigella sativa). Industrial Crops and Products. 112: 741-748.

Rostami, H., Nikoo, A. M., Rajabzadeh, G., Niknia, N. and Salehi, S. 2018. Development of cumin essential oil nanoemulsions and its emulsion filled hydrogels. Food Bioscience. 26: 126132.

Sahana, K., Nagarajan, S. and Mohan Rao, L. J. 2011. Cumin (Cuminum cyminum) Seed Volatile Oil: Chemistry and Role in Health and Disease Prevention. Nuts 
and Seeds in Health and Disease Prevention. 50: 417-427.

Sowbhagya H.B. 2013.Chemistry, technology, and nutraceutical functions of cumin (Cuminum cyminum). An Overview, Critical Reviews in Food Science and Nutrition. 53: 1-1

\section{How to cite this article:}

Dhanni Devi, S.B. Gupta and Mishra, B.K. 2019. Isolation and Characterization of Potential Zn Solubilizing Rhizobacteria from Cumin (Cuminum cyminum).

Int.J.Curr.Microbiol.App.Sci. 8(07): 1865-1880. doi: https://doi.org/10.20546/ijcmas.2019.807.222 